\title{
PHENOBARBITAL AND THE SHOULDER-HAND SYNDROME
}

\author{
BY \\ J. K. VAN DER KORST, H. COLENBRANDER, AND A. CATS \\ From the Department of Rheumatology, University Hospital, Leyden, Netherlands
}

Three cases of severe bilateral shoulder-hand syndrome were observed within a few months of each other, all three in patients who were being treated with phenobarbital because of epilepsy; one received phenytoin as well. In one of these cases the diagnosis of epilepsy became improbable; the electro-encephalogram revealed no signs of epilepsy, but rather of chronic barbiturate poisoning. A possible relationship between barbiturate treatment and the shoulder-hand syndrome was therefore investigated.

\section{Material and Methods}

The case histories of all patients with shoulder-hand syndrome admitted to the Department of Rheumatology during the years 1954-64 were reviewed. The original diagnosis in each case was checked according to the following criteria: pain and/or stiffness of the shoulder; diffuse swelling or atrophy of the soft tissues of the homolateral hand. Patients with fractures or dislocations of the homolateral extremity and patients with joint disease other than mild osteo-arthritis were excluded. The shoulder-hand syndrome was regarded as bilateral if both hands showed dystrophic changes.

Two groups of patients, of the same number, matched for age and sex but otherwise unbiased, were used as controls: one group had scapulohumeral periarthritis and the other cervicobrachial neuralgia.

In all three groups other illnesses and medication prior to the onset of the presenting syndrome were ascertained.

\section{Results}

75 cases of the shoulder-hand syndrome were available for analysis (Table I). In 29 cases both hands were affected. There was a slight preponderance of males. The ages ranged from 22 to 81 years, the majority were from the older age groups, 37 being over 60 years old.
TABLE I

SEX, AGE, AND SITE OF LESION IN 75 PATIENTS WITH SHOULDER-HAND SYNDROME

\begin{tabular}{|c|c|c|c|c|c|c|c|}
\hline Sex & $\begin{array}{l}\text { Male } \\
\text { Female }\end{array}$ & $\begin{array}{l}\ldots \\
\cdots\end{array}$ & 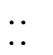 & 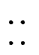 & 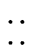 & $\ddot{\cdots}$ & $\begin{array}{l}41 \\
34\end{array}$ \\
\hline Age (yrs) & $\begin{array}{l}\text { Mean } \\
\text { Standard } \\
\text { Range }\end{array}$ & $\ddot{\mathrm{De}}$ & 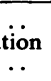 & $\begin{array}{l}\cdots \\
\cdots\end{array}$ & $\begin{array}{l}\cdots \\
\cdots\end{array}$ & $\begin{array}{l}\ddot{ } \\
\therefore\end{array}$ & $\begin{array}{r}58 \cdot 5 \\
\pm 12.4 \\
22-81\end{array}$ \\
\hline Site & $\begin{array}{l}\text { Bilateral } \\
\text { Unilatera }\end{array}$ & $\mathrm{al}^{\circ}$ & $\ldots$ & $\ddot{x}$ & . & 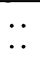 & $\begin{array}{l}29 \\
46\end{array}$ \\
\hline
\end{tabular}

In 33 patients sedatives had been used before and during the development of the syndrome; this was the case with only eight of the 75 cases of scapulohumeral periarthritis and one of the 75 cases of cervicobrachial neuralgia (Table II). Phenobarbital could be identified as the drug used in 25 patients with the shoulder-hand syndrome and in two patients with scapulohumeral periarthritis. This difference between those with shoulder-hand syndrome and the two control groups appeared to be significant $(P<0.01)$. On the other hand, no significant difference was found between the three groups in regard to other barbiturates, undefined sedatives, or other drugs.

TABLE II

DRUGS USED BEFORE ONSET OF PRESENTING SYNDROME

\begin{tabular}{l|c|c|c}
\hline \multicolumn{1}{c|}{ Drug } & $\begin{array}{c}\text { Shoulder- } \\
\text { hand } \\
\text { Syndrome }\end{array}$ & $\begin{array}{c}\text { Scapulo- } \\
\text { humeral } \\
\text { Periarthritis }\end{array}$ & $\begin{array}{c}\text { Cervico- } \\
\text { brachial } \\
\text { Neuralgia }\end{array}$ \\
\hline $\begin{array}{l}\text { Phenobarbital } \\
\text { Other barbiturates }\end{array}$ & 25 & 2 & - \\
$\begin{array}{l}\text { Unspecified sedatives } \\
\text { Phenytoin }\end{array}$ & 6 & 1 & $\overline{1}$ \\
Isoniazid & 4 & - & - \\
Anticoagulants & 4 & - & - \\
Tranquillizers & 2 & 3 & 2 \\
\hline
\end{tabular}

A few drugs not mentioned were used only in a single instance. 
In most of the patients suffering from shoulderhand syndrome coincident with phenobarbital treatment involvement was bilateral (Table III). Nineteen of 29 patients with bilateral shoulder-hand syndrome were treated with phenobarbital, as against only six of 46 with unilateral involvement. This difference is significant $(P<0.01)$.

DRUGS USED BEFORE ONSET OF SHOULDER-HAND

\begin{tabular}{l|c|c|c}
\hline \multirow{2}{*}{ Drug } & \multicolumn{2}{|c|}{ Shoulder-hand Syndrome } \\
\cline { 2 - 4 } & Bilateral & Unilateral & Total \\
\hline Phenobarbital & 19 & 6 & 25 \\
Unspecified sedatives & 5 & 1 & 6 \\
Phenytoin & 4 & - & 4 \\
Isoniazid & 3 & 1 & 4 \\
\hline
\end{tabular}

Of the ten patients with bilateral shoulder-hand syndrome who had not previously taken phenobarbital, five were using other sedatives, and three isoniazid.

The reasons for giving phenobarbital treatment varied widely (Table IV), but epilepsy proved to be the commonest. Nine cases of concurrent epilepsy and shoulder-hand syndrome were found, of which seven were bilateral. In only one of the patients with unilateral involvement had the diagnosis of epilepsy not been made before the onset of the shoulder-hand syndrome, but this patient had been treated for some years with phenobarbital for another reason, viz. epigastric pain. Epilepsy was the only condition found more commonly $(P<0.01)$ in patients with the shoulder-hand syndrome than in the two control groups (in which it was absent).

TABLE IV

INDICATIONS FOR PHENOBARBITAL TREATMENT, AND SITE OF LESION

\begin{tabular}{|c|c|c|}
\hline \multirow{2}{*}{ Diagnosis } & \multicolumn{2}{|c|}{ Shoulder-hand Syndrome } \\
\hline & Bilateral & Unilateral \\
\hline $\begin{array}{l}\text { Epilepsy } \\
\text { Psychosis/neurosis } \\
\text { Pituitary tumour (operated) } \\
\text { Angina pectoris } \\
\text { Hypertension } \\
\text { Chronic bronchitis } \\
\text { Pneumonia } \\
\text { Menière's syndrome } \\
\text { Epigastric pain } \\
\text { Insomnia } \\
\text { Headache } \\
\text { Nervousness }\end{array}$ & $\begin{array}{l}7 \\
4 \\
1 \\
\overline{1} \\
\overline{2} \\
\overline{2} \\
\overline{2} \\
1 \\
-\end{array}$ & $\begin{array}{l}\frac{1}{2} \\
\overline{1} \\
\overline{1} \\
\overline{1} \\
\overline{1} \\
\overline{1} \\
\overline{1}\end{array}$ \\
\hline Total & 19 & 6 \\
\hline
\end{tabular}

In sixteen of the 25 patients who had received phenobarbital before the shoulder-hand syndrome developed, the daily amount given could be traced: all had received $100 \mathrm{mg}$. or more (Table V). Doses
TABLE $V$

DOSE AND DURATION OF PHENOBARBITAL TREATMENT, AND SITE OF LESION

\begin{tabular}{|c|c|c|c|}
\hline \multirow{2}{*}{\multicolumn{2}{|c|}{ Phenobarbital Therapy }} & \multicolumn{2}{|c|}{ Shoulder-hand Syndrome } \\
\hline & & \multirow[b]{2}{*}{$\begin{array}{c}\text { Bilateral } \\
4 \\
4 \\
2 \\
1 \\
2 \\
6\end{array}$} & \multirow{2}{*}{$\begin{array}{c}\text { Unilateral } \\
\overline{3} \\
\overline{-} \\
\overline{3}\end{array}$} \\
\hline $\begin{array}{l}\text { Daily Dose } \\
\text { (mg.) }\end{array}$ & $\begin{array}{l}100 \\
150 \\
200 \\
300 \\
\text { Over 300 } \\
\text { Not known }\end{array}$ & & \\
\hline Duration & $\begin{array}{l}\text { Less than } 4 \text { wks } \\
1-11 \text { mths } \\
1-10 \text { yrs } \\
\text { Over } 10 \text { yrs } \\
\text { Not known }\end{array}$ & $\begin{array}{l}3 \\
5 \\
4 \\
5 \\
2\end{array}$ & $\begin{array}{l}2 \\
1 \\
3 \\
- \\
-\end{array}$ \\
\hline
\end{tabular}

of more than $150 \mathrm{mg}$. a day were found in cases of bilateral involvement only. The duration of treat $\mathrm{G}$ ment before the onset of the shoulder-hand syndromer varied from a few weeks to more than 20 years (Table V). Treatment appeared to have gone onp longer in cases of bilateral involvement than in unilateral cases.

With the exception of a predominance of bilatera involvement, no clear difference in the clinicas picture of the shoulder-hand syndrome could be्ष made out between those patients who had received previous phenobarbital treatment and those w\$क had not. The acute symptoms of the shoulder-hap syndrome-burning pain, oedematous swellifige hyperhydrosis, etc.-had subsided within 6 months leaving no signs of atrophy or contracture in onl five patients, all with unilateral involvemento These were the youngest in the whole group (ages varying between 22 and 41 years) and none had bee treated with sedatives. In the other patients including all those treated with phenobarbital, the hypertrophic stage lasting about 3 to 9 months was followed by atrophic changes of the hand(s) and contractures of the fingers of greater or lesse severity. Continuation of the phenobarbital treate ment after the onset of the shoulder-hand syndrome did not appear to affect the prognosis.

\section{Discussion}

In this series, one-third of all cases of the shouldere hand syndrome occurred during phenobarbitalf treatment, with a striking preponderance of bilateral involvement. Some decades ago, in the Frenc literature, attention was drawn to the occurrence of arthralgia, sometimes accompanied by contracture during treatment with barbiturates, especialle phenobarbital (Maillard and Renard, 1925; Maillare and Thomazi, 1931; Bériel and Barbier, 1934; Castin and Gardien, 1934). This condition, called 
"rhumatisme barbiturique" or "rhumatisme gardénalique", was encountered almost exclusively in older people treated for different conditions with barbiturates. As far as can be assessed from these papers, contractures were reported only in the shoulder, wrist and/or finger joints. Some cases, with a strong clinical resemblance to the shoulder-hand syndrome, were also described in the Scandinavian literature (Lövgren, 1948).

The shoulder-hand syndrome, sometimes accompanied by generalized joint pains, has recently been noted in patients treated with isoniazid for tuberculosis (Good, Green, and Zarafonetis, 1965; Dubra, Agüero, Chamoles, Marengo, and Epelbaum, 1965). In attributing a causative role to this drug, it is argued that it is known in experimental animals to cause neuropathy-perhaps by interfering with pyridoxine metabolism. As far as is known, no such effect of barbituric-acid derivatives has been described. While symptoms of the shoulder-hand syndrome during isoniazid treatment become usually manifest about 4 weeks after the onset of treatment, the duration of phenobarbital treatment before the onset of the shoulder-hand syndrome ranged from a few weeks to more than 10 years. It seems improbable, therefore, that phenobarbital plays a similar role to that of isoniazid in the pathogenesis.

Obviously there were widely divergent reasons for using phenobarbital in our patients. Nevertheless it might be contended that phenobarbital consumption is only a common denominator of subjects who are otherwise prone to develop the shoulder-hand syndrome. Thus it has been claimed that anxiety neurosis predisposes to this syndrome (Kahlmeter, 1930), and it can be imagined that in this type of patient sedatives are more readily prescribed. However, features of neurotic personality structure have also been demonstrated both in patients with scapulohumeral periarthritis and in those with cervicobrachial neuralgia, as compared with a healthy control group (Oesterreicher and van Dam, 1964). In patients with the former conditions, a significantly lower incidence of phenobarbital usage was found than in the group with the shoulder-hand syndrome.

The information presented therefore appears to indicate that phenobarbital might - by some mechanism as yet unknown-predispose to the occurrence of the shoulder-hand syndrome, although more direct evidence is still required.

\section{Summary}

A history of prior treatment with phenobarbital, of varying duration and dose, was found to be present in nineteen out of 29 consecutive cases of bilateral shoulder-hand syndrome and in six out of 46 patients with unilateral involvement. A significantly lower incidence of phenobarbital consumption was found in two matched control groups comprising cases of scapulohumeral periarthritis and cervicobrachial neuralgia respectively. The possibility that treatment with phenobarbital predisposes to the shoulder-hand syndrome is discussed.

\section{REFERENCES}

Bériel and Barbier, J. (1934). Presse méd., 42, 67. Castin, P., and Gardien, P. (1934). Ibid., 42, 1536. Dubra, F. A., Agüero, J. G., Chamoles, N., Marengo, R., and Epelbaum, A. (1965). Rev. Asoc. méd. argent., $79,165$.

Good, A. E., Green, R. A., and Zarafonetis, C. J. D. (1965). Ann. intern. Med., 63, 800.

Kahlmeter, G. (1930). Acta rheum. (Amst.), 2, No. 6, p. 20.

Lövgren, O. (1948). Svensk. Läk.-Tidn., 45, 234.

Maillard, G., and Renard, G. (1925). Presse méd., 33, 315.

— and Thomazi, P. (1931). Ibid., 39, 851.

Oesterreicher, W., and van Dam, G. (1964). Arthr. and Rheum., 7, 670.

Phénobarbital et syndrome épaule-main

\section{RÉSUMÉ}

Un traitement par le phénobarbital avec des doses et une durée variable fut trouvé dans les antécédents de 19 sur 29 cas de syndrome épaule-main bilatéral et chez 6 sur 46 malades présentant une atteinte unilatérale. Dans deux groupes de témoins d'âge et de sexe similaires comprenant respectivement des cas de périarthrite scapulo-humérale et de névralgie cervico-brachiale on trouva une consommation de phénobarbital significativement plus basse. On discute l'hypothèse d'une prédisposition possible au syndrome épaule-main à la suite de traitement par le phénobarbital.

\section{Fenobarbital y el síndrome hombro-mano}

\section{SUMARIO}

Una historia de tratamiento previo con fenobarbital de dosis y duración variable fué descubierta en 19 de 29 casos de síndrome hombro-mano bilateral y en 6 de 46 enfermos afectos unilateralmente. En dos grupos de testigos de edad y sexo similares comprendiendo respectivamente casos de periartritis escapulo-humeral y neuralgia cervico-braquial el consumo de fenobarbital fué significativamente más bajo. Se discute la posibilidad de que el tratamiento con fenobarbital predispone al síndrome hombro-mano. 